Лисина Наталья Леонидовна

кандидат юридических наук, доцент, заведующий кафедрой трудового, экологического права и гражданского процесса Юридического института

Кемеровского государственного университета

\section{ПРАВОВАЯ ОХРАНА ВОДНЫХ ОБЪЕКТОВ В ГОРОДАХ: ОТ ПОСТАНОВКИ К РЕШЕНИЮ ПРОБЛЕМЫ}

\section{Аннотация:}

В статье рассматриваются особенности осуществления мероприятий по охране водных объектов в городах на основе действующего законодательства. Выявляются проблемы режима правовой охраны водных объектов в городах, требующие решения с учетом местных и региональных особенностей. Рассмотрены требования законодательства (Водный кодекс РФ, Земельный кодекс $\boldsymbol{P}$, Градостроительный кодекс $\boldsymbol{P \Phi}$, указы президента) и их особенности. Автор предлагает основные направления совершенствования охраны и улучшения состояния водных объектов в городах основанные на комплексности правовых, архитектурно-градостроительных, социально-экономических и иных мер, потенциале природно-социальной системы, специфике взаимосвязей ее элементов: интеграция мероприятий правовой охраны водных объектов, совершенствование децентрализованной управленческой деятельности за состоянием водных объектов в городах, совершенствование правового института оценки воздействия на окружаюшую среду.

Ключевые слова:

воды, водные объекты, окружающая среда, правовая охрана, город, водное законодательство, экологическое законодательство, водоохранные зоны.
Lisina Natalia Leonidovna

PhD in Law, Associate Professor, Head of the Department of Labor, Environmental Law and Civil Procedure, Law Institute, Kemerovo State University

LEGAL PROTECTION OF WATER BODIES IN CITIES: FROM PROBLEM STATEMENT TO ITS SOLUTION

Keywords: water, water bodies, environment, legal protection, city, water law, environmental law, water protection zones. the legal institution of the environmental impact as sessment.

Дефицит водных ресурсов - проблема выживания всех живых существ на Земле. Для каждой страны воды являются основным природным ресурсом [1, р. 55]. Человек всегда тяготел к водным объектам, рядом с ними появлялись поселения. Водные объекты в городе, оставаясь компонентами природной среды и природными ресурсами, выполняют ряд функций (экологическую, социально-экономическую, природно-инженерную [2, с. 25]). Они определяют не только климатические особенности и экологический каркас города, но и градостроительную ситуацию. Однако функции водных объектов проявляются в полной мере лишь в условиях благоприятной окружающей среды. Нарушение баланса в единой природно-социальной системе города влечет разлад в функционировании вод.

Сильное загрязнение почв в городах, рост объема загрязнений с территорий урбанизации, промышленных производств, свалок отходов, автомобильных дорог, нарушение режима водоохранных зон, сброс сточных вод в городах без какой-либо очистки или недостаточно очищенных не способствуют улучшению состояния вод даже на фоне медленного снижения поступлений загрязняющих веществ в водные объекты в городах [3, с. 58]. Загрязнение воды происходит и за счет попадания в водные объекты вредных химических веществ, в том числе нитратов, количество которых в составе сточных вод за последние 10-15 лет возросло более чем в 4 раза.

Серьезную угрозу разрушения зданий и сооружений в городах несет в себе загрязнение подпочвенных вод. Природно-климатические и техногенно-антропогенные факторы не способствуют благоприятному состоянию качества воды в водных объектах для рекреационных целей.

Несмотря на проводимые на протяжении многих лет природоохранные мероприятия, большинство водных объектов продолжают оставаться загрязненными, а такие крупнейшие реки, как 
Волга, Обь и Енисей, вообще потеряли питьевое значение. К слову, обеспечение населения Российской Федерации качественной питьевой водой до сих пор остается приоритетным. В 2017 г. лишь в шести субъектах РФ источники централизованного питьевого водоснабжения соответствовали санитарно-эпидемиологическим требованиям. На качество и безопасность питьевой воды влияют само состояние источников питьевого водоснабжения, отсутствие зон санитарной охраны, состояние водопроводной и распределительной сетей. По данным Роспотребнадзора, не наблюдается улучшения питьевой воды по санитарно-химическим показателям [4, с. 28-29]. В связи с этим в очередной раз в мае 2018 г. президентом РФ [5] проблемы экологического оздоровления водных объектов и повышения качества питьевой воды для жителей населенных пунктов были возведены в ранг приоритетных, требующих решения и значительного улучшения в ближайшие шесть лет.

Однако за последние годы была выстроена определенная система законодательства в области охраны водных объектов и водопользования, которую образуют нормативные правовые акты, регулирующие охранительные отношения по поводу водных объектов; нормативные правовые акты, регламентирующие одну из составляющих социального аспекта единой природно-социальной системы - обеспечение качественной питьевой водой, которая является «конечным продуктом» использования водных объектов для целей питьевого водоснабжения; а также нормативные правовые акты, регламентирующие деятельность субъектов экологических отношений по охране водных объектов и их использованию, в том числе по эксплуатации объектов водного хозяйства, осуществлению деятельности по питьевому и хозяйственно-бытовому водоснабжению в городе, осуществлению соответствующих платежей. Кроме того, насчитывается более 220 санитарных правил и норм, гигиенических нормативов, методических рекомендаций, указаний, содержащих конкретные санитарно-гигиенические требования для питьевой воды и водоснабжения населенных мест, а также по санитарной охране водоемов и водоотведению в населенных местах.

Правовая охрана вод является частью мероприятий по охране окружающей среды как интегрированного объекта. При этом общие организационно-правовые инструменты охраны окружающей среды конкретизируются в водном законодательстве в силу особых природных свойств и характеристик водных объектов, их значения для жизнедеятельности человека и природной среды и находят свое выражение в таких мероприятиях, как гидрографическое и водохозяйственное районирование, резервирование источников питьевого и хозяйственно-бытового водоснабжения, установление целевых показателей качества воды в водных объектах и других.

Следует заметить, что местонахождение водных объектов в городе предопределяет необходимость учета особенностей их существования в единой природно-социальной системе, характер правовых связей в ней и ее потенциал. В противном случае невозможно говорить об эффективности правовых мер по охране водных объектов. Только при осуществлении интегрированного комплекса мер охраны водных объектов в городе, включающего не только правовые, но и санитарные, градостроительные, инженерные, экономические решения, можно добиться улучшения состояния водных объектов.

Водные объекты - часть единой природно-социальной системы в городе, они способны меняться и даже утрачивать свои полезные функции или исчезать под воздействием природных и антропогенных факторов. Поэтому городам необходима совершенная система наблюдений за состоянием водных объектов во взаимосвязи с наблюдением за состоянием других компонентов природной среды для оценки экологических рисков. Также необходимо практическое осуществление мероприятий, направленных на поддержание и улучшение водных объектов в городе через систему мероприятий по улучшению состояния других компонентов природной среды и природных объектов, предусмотрев рекультивацию прилегающих земель, их озеленение и обустройство ландшафртов, сохранение лесных и иных насаждений в городе, а также биологического разнообразия.

На состояние водных объектов в городе напрямую влияет освоение территории в процессе градостроительства (степень запечатывания почвы, характер и плотность застройки, процент озеленения территории и пр.). Поскольку градостроительство, как правило, всегда связано с нарушением целостности природной среды и ее компонентов в городе, важно не только поддерживать состояние существующих, но и создавать новые водные объекты в городе для улучшения как природно-климатических, так и социально-культурных условий. Так, градостроительное планирование и застройка территории города должны осуществляться с учетом естественных процессов функционирования водной среды в городе и взаимозависимости ее состояния и природных и антропогенных факторов.

Известно, что немаловажное значение при принятии решений о планируемой реализации проектов и размещении объектов, оказывающих или могущих оказать воздействие на окружающую среду, имеет оценка воздействия на окружающую среду. При наличии водного объекта в городе в предполагаемом месте размещения объекта целесообразно проводить экологическую оценку состояния водной системы территории, а также экологических рисков с учетом социально- 
экономических и техногенных фракторов территории. А уже при реализации проекта и эксплуатации объекта следует осуществлять водопользование или иную деятельность, могущую оказать воздействие на состояние водных объектов в городе, с применением новых технологий и инженерно-технологических решений, которые основаны на потенциале единой природно-социальной системы и научно обоснованном методическом подходе к водопользованию (мы называем такой подход принципом рационализации).

Однако в условиях изменяющейся с 1 января 2019 г. системы экологического нормирования переход на наилучшие доступные технологии лишь часть решения проблемы, поскольку не охватывает всех «загрязнителей». Необходимо признание обязательных региональных экологических нормативов, которые позволят учесть местные условия и особенности состояния окружающей среды в городе, а также иных мер правовой охраны (экологической стандартизации, экологической сертификации, экологического страхования).

Также заметим, что в последние годы произошли серьезные изменения правовых норм, устанавливающих правовой режим водоохранных зон, прибрежных защитных полос и зон санитарной охраны. Не вызывает сомнения тот факт, что задача охраны водных объектов от загрязнения достигается путем установления ограничений эксплуатации сопредельных природных ресурсов и хозяйственной деятельности, главным образом установлением водоохранных и санитарно-защитных зон [6, с. 415]. К сожалению, установление правовых режимов охраны на практике осложнено неоднозначностью правовых режимов тех земель, которые примыкают к водным объектам, если они пролегают в границах населенных пунктов, где, по общему правилу, правовой режим использования территории определяется земельным законодательством применительно к такой категории земель, как земли населенных пунктов, и законодательством о градостроительной деятельности.

Несмотря на особенности, а местами противоречивость правовых норм в установлении правового режима земель населенных пунктов, полагаем, что приоритет в определении правового режима использования и охраны водоохранных зон следует отдавать водному законодательству. Водоохранные зоны, равно как и зоны санитарной охраны источников питьевого и хозяйственно-бытового водоснабжения, отнесены градостроительным законодательством к зонам с особыми условиями использования территорий, которые подлежат отражению в документах территориального планирования, а также документации по планировке территории. Одновременно особые условия использования земельных участков и режим хозяйственной деятельности в охранных и санитарно-защитных зонах рассматриваются в п. 2 ст. 56 Земельного кодекса РФ [7] ограничениями прав на землю.

Кроме того, часть 3 ст. 4 Градостроительного кодекса РФ [8] содержит положение о том, что к градостроительным отношениям применяется земельное, лесное, водное и иное законодательство, если данные отношения не урегулированы законодательством о градостроительной деятельности. Порядок установления зон с особыми условиями использования территорий и их правовой режим Градостроительным кодексом РФ не установлен, в нем сделана лишь одна важная, на наш взгляд, оговорка в ст. 41.1, касающаяся подготовки документации по планировке территории. Согласно указанной статье, при подготовке документации по планировке территории до установления границ зон с особыми условиями использования территории учитываются размеры этих зон и ограничения по использованию территории в границах таких зон, которые устанавливаются в соответствии с законодательством Российской Федерации (выделено мной. Н. Л.). Таким образом, при отсутствии урегулирования данного вопроса градостроительным законодательством следует допустимый вывод о применении водного законодательства в части установления правового режима водоохранных зон в целях охраны водных объектов и введения ограничений на использование земель (земельных участков) в их границах, т. е. специального правового режима охраны. Заметим, что применительно к охране водных объектов, независимо от их территориального нахождения (в границах города или за его пределами), требования водного законодательства сформулированы в форме запрещений.

Требования-запрещения характерны и для обеспечения режима правовой охраны водных объектов от биологического воздействия в зонах санитарной охраны источников водоснабжения. Эти зоны также отнесены градостроительным законодательством к зонам с особыми условиями использования территории и должны быть показаны в документации о градостроительном планировании и планировке территории. Однако ограничения и условия использования земель (земельных участков) в пределах данных зон устанавливаются специальными нормами и правилами с учетом различных факторов (вид источника водоснабжения, характер загрязнения, степень естественной защищенности водного объекта, гидрогеологические и гидрологические условия).

Кроме того, известно, что Водный кодекс РФ [9] устанавливает принцип бассейнового управления водными ресурсами. Однако такой подход характерен и оправдан лишь для государ- 
ственного управления водными ресурсами, осуществляемого специально уполномоченными фредеральными органами исполнительной власти, деятельность которых в современных условиях жестко регламентирована и ограничена в силу различных причин. Для обеспечения системности управленческой деятельности и учета специфики местных условий и состояния водных объектов, охватывающих территорию более одного города или иного населенного пункта, целесообразно придание управленческой деятельности межрегионального и межмуниципального характера, в том числе посредством обеспечения согласованных правовых мер охраны крупных, протяженных водных объектов (на основании соглашений, заключаемых между субъектами РФ или муниципальными образованиями, о совместной разработке и реализации проектов «реконструкции» водных объектов в городах и др.).

Таким образом, решение проблем правовой охраны водных объектов в городах должно осуществляться в первую очередь по следующим направлениям:

- интеграция мероприятий правовой охраны водных объектов с учетом местных особенностей единой природно-социальной системы в городе через сближение экологического и санитарно-эпидемиологического законодательства и экологизацию законодательства о градостроительной деятельности;

- совершенствование децентрализованной управленческой деятельности за состоянием водных объектов в городах, основанной на согласованных межрегиональных и межмуниципальных правовых мерах и мероприятиях;

- совершенствование правового института оценки воздействия на окружающую среду в части оценки экологических рисков и оценки состояния водной системы территории города при планировании градостроительных, хозяйственных и иных проектов, а также при их реализации.

В целях охраны водных объектов указанные концептуальные положения, на наш взгляд, должны послужить основой дальнейшего развития законодательства, реализации государственных и муниципальных программ экологического, социально-экономического улучшения состояния территорий.

\section{Ссылки:}

1. Caponera D.A. National and International Water Law and Administration: Selected Writing. Kluwer Law International, 2003. $446 \mathrm{p}$.

2. Эксплуатация, реконструкция и охрана водных объектов в городах / И.Г. Бойкова, В.В. Волшаник, Н.Б. Карпова, В.Г. Печников, Е.И. Пупырев. М., 2008. 256 с.

3. О состоянии и об охране окружающей среды Российской Федерации в 2016 г. : государственный доклад. М., 2017. $760 \mathrm{c}$.

4. О состоянии санитарно-эпидемиологического благополучия населения в Российской Федерации в 2017 г. : государственный доклад. М., 2018. 268 с.

5. О национальных целях и стратегических задачах развития Российской Федерации на период до 2024 года : указ Президента РФ от 7 мая 2018 г. № 204 : по сост. на 19 июля 2018 г. // Собрание законодательства РФ. 2018. № 20. 14 мая. Ст. 2817.

6. Крассов О.И. Природные ресурсы России : комментарий законодательства. М., 2002. 814 с.

7. Земельный кодекс Российской Федерации : федер. закон от 25 окт. 2001 г. № 136-Ф3 : по сост. на 3 авг. 2018 г. // Собрание законодательства РФ. 2001. № 44. 29 окт. Ст. 4147.

8. Градостроительный кодекс Российской Федерации : федер. закон от 29 дек. 2004 г. № 190-Ф3 : по сост. на 3 авг. 2018 г. // Там же. 2005. № 1 (часть 1). 3 янв. Ст. 16.

9. Водный кодекс Российской Федерации : федер. закон от 3 июня 2006 г. № 74-Ф3 : по сост. на 3 авг. 2018 г. // Там же. 2006. № 23. 5 июня. Ст. 2381.

\section{References:}

Boykova, IG, Volshanik, VV, Karpova, NB, Pechnikov, VG \& Pupyrev, El 2008, Exploitation, Reconstruction and Protection of Water Bodies in Cities, Moscow, 256 p., (in Russian).

Caponera, DA 2003, National and International Water Law and Administration: Selected Writing, Kluwer Law International, $446 \mathrm{p}$.

Krassov, OI 2002, Natural Resources of Russia: Legal Comments, Moscow, 814 p., (in Russian).

On the State and on the Protection of the Environment of the Russian Federation in 2016: a State Report 2017, Moscow, 760 p., (in Russian).

On the State of the Public Health and Epidemiological Well-Being of the Population in the Russian Federation in 2017: a State Report 2018, Moscow, 268 p., (in Russian) 